\title{
Minister set to reform Australia's universities
}

Peter Pockley, Sydney

Australia's hard-pressed universities can expect no financial relief from the new government until May of next year at the earliest, says Brendan Nelson, the country's new minister for education, science and training.

But Nelson, a physician and former president of the Australian Medical Association who looks set to bring considerable energy and influence to his position, pledged to enact reforms that will help Australian universities to carry out internationally competitive research.

"The situation is not sustainable without reform," says Nelson. He says that he will immediately set up a consultative panel to help him prepare a university-reform package, for consideration by Australia's cabinet within a year. The reforms may open up the possibility of extra funding in the May 2003 budget, he says.

"The universities have been reviewed to death," says Nelson. "We know what the problems and challenges are." The new panel will avoid revisiting the ground covered in previous reviews, he says, and will instead propose concrete changes in university governance, working conditions and the way in which specialist strengths are split between universities. Nelson wants to see "one or two universities become world-class", but acknowledges that this is "not likely under current funding arrangements".

After its November re-election, the Liberal Party government of Prime Minister John Howard shifted responsibility for Australia's science agencies from the department of industry to Nelson's department. Nelson pledges to appoint a scientific adviser in his office "who will have credibility in the science community and will live and breathe science".

Nelson has wasted little time in challeng-

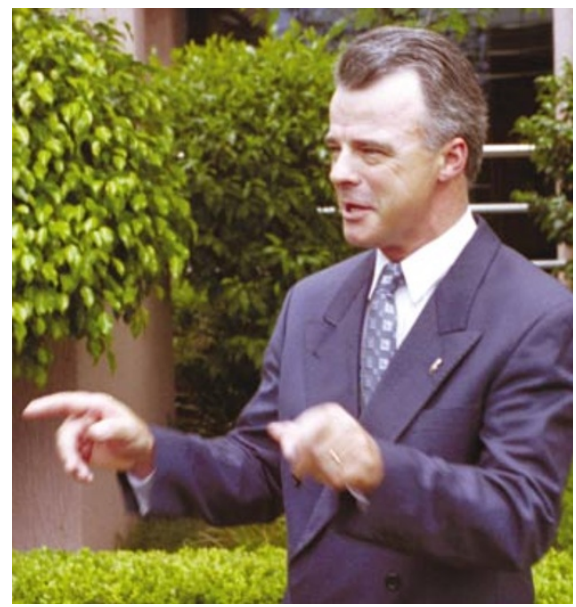

Facing the challenge: Brendan Nelson says he wants to concentrate on concrete changes. ing the universities to address their own shortcomings: at a recent meeting with vicechancellors, for example, he told them that they had lost the support of "the everyday person". Last year, the vice-chancellors lobbied for an extra A $\$ 1$ billion (US $\$ 515$ million) a year to make up for cuts made since Howard came to power in 1996, but Nelson has made it clear that they will have to settle for less. The government is committed to an "innovation package" containing A \$2.9 billion in new funding over five years (see Nature 409,655; 2001), but has delivered only A $\$ 160$ million for this year.

Nelson was once something of a maverick in Howard's staunchly conservative government - he wore an earring when he first entered parliament in 1996. Now, however, as the measured and articulate face of the government's science policy, his style contrasts with the abrasiveness of his predecessor, David Kemp, whose own reform package for the universities was rapidly disowned by the government (see Nature 402, 113; 1999). Nelson's openness to discussion has been welcomed by scientific societies. The Australian Academy of Science and the Federation of Australian Scientific and Technological Societies have already drawn up their own lists of ideas for the new minister and his consultative group to chew on.

\section{Undersea plan leaves wrecks to rest in peace}

\section{Quirin Schiermeier, Munich}

Archaeologists in northern Europe are

planning a fresh approach to the study and conservation of shipwrecks.

Under a project backed by the European Union, researchers will investigate the wrecks in situ and use technology to let the public explore virtual images of them, without the expense and physical disruption of hauling the structures to the surface.

"Shipwrecks are best studied and preserved in their natural environments," says Sallamaria Tikkanen, a curator at the Maritime Museum of Finland, which will coordinate the project.

The idea of opening shipwrecks up to the public but leaving them in place gained momentum after the discovery in 1999 of the wreck of the Vrouw Maria. This eighteenthcentury trade ship, which sank off the coast of Finland, is particularly well preserved. It will now be left in place and studied as part of the new project.

"Shipwrecks are cultural possessions, and we have a responsibility to preserve them for future generations," says Hauke Jöns, a conservationist at the Archaeological State Museum of Mecklenburg-Vorpommern in

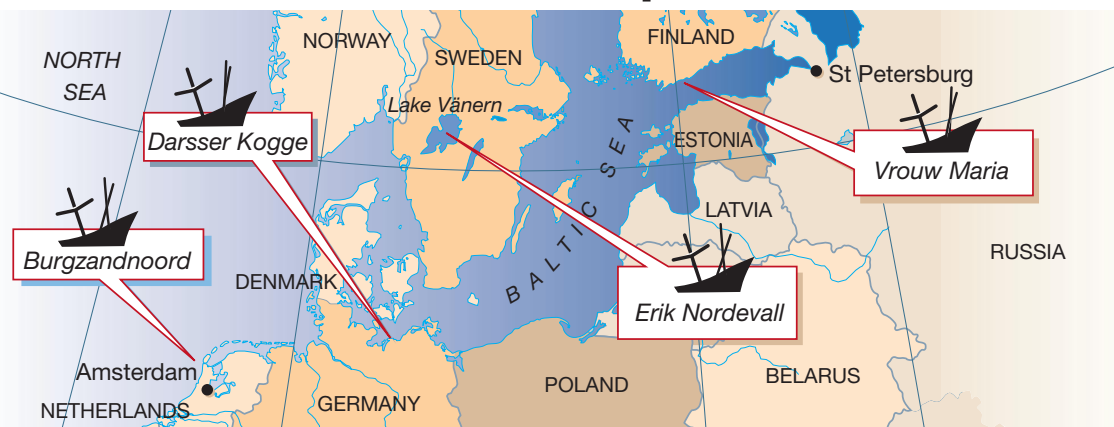

Four ships selected for study were seen as representative of the wrecks off northern Europe's coasts.

Germany. "But they should not be

removed from the place where they have met their fate."

Other shipwrecks included in the project are the Erik Nordevall, a nineteenth-century paddle steamer that sank in Sweden's Lake Vänern; the Burgzand Noord in the Wadden Sea off Holland; and the Darsser Kogge, a medieval ship discovered in the sea close to the German town of Prerowstrom, near Rostock.

The project includes research on the process of degradation and on the problem of Teredo navalis, a shipworm that feeds on timber. The project will also explore various conservation methods, such as covering shipwrecks in sarcophagus-like tarpaulins and using sandbags to protect them from undersea currents.

Equipment at each site will measure salinity, temperature, water movement and the prevalence of microorganisms, warning the researchers of changes that could cause the wrecks to deteriorate.

The shipwrecks will be extensively filmed, and the resulting images will allow Internet users and museum visitors to take 'virtual tours' of them. 